\title{
Editorial: Nature of Author
}

'There's hope for Broad', said Dr A. A. Luce, philosopher, editor of Berkeley, Senior Fellow and Vice-Provost of Trinity College Dublin. The year was 1950, and the Vice-Provost was catechising the junior Fellow of St John's College, Cambridge, visiting under the kindly provisions of the 'amicable concord' that subsists between the two Colleges. The visitor had called on the Vice-Provost to make a formal declaration, before being admitted to the Library, that he would not steal or burn or disfigure any of the books. Dr Luce's official, almost stern demeanour had relaxed when it proved possible for the supplicant to read the declaration in Latin, with every appearance of understanding. To be a classical don at Cambridge was clearly a respectable condition. The brows darkened again when it was revealed that the young classic was also a young philosopher. The Vice-Provost allowed no scruple of hospitality to inhibit the severity of his commination. Wittgenstein, Wisdom, Braithwaite: as the names were submitted one by one, anathema was pronounced. Only Ewing escaped whipping. The fifth Cambridge philosopher of that generation escaped Luce's memory and his inquisitorial attention. When he was reminded of Broad he softened his tone. "Broad-yes, there's hope for Broad. But there's one thing that worries me about Broad. Does he have a sense of humour?'

Counsel for the defence, though initially startled by the implausibility of the accusation, began to assemble some of the evidence. What about the Preface to The Mind and its Place in Nature?

I had no intention of inflicting another book on the public so soon after my Scientific Thought; and I should certainly not have done so had I not been asked to give the Tarner Lectures. I think I can promise that it will be long before I offend again. In the meanwhile I retire to my well-earned bath-chair, from which I shall watch with a fatherly eye the philosophic gambols of my younger friends as they dance to the highly syncopated pipings of Herr Wittgenstein's flute.

And on the next page:

I shall no doubt be blamed by certain scientists, and, I am afraid, by some philosophers, for having taken serious account of the alleged facts which are investigated by Psychical Researchers. I am wholly impenitent about this. The scientists in question seem to me to confuse the Author of Nature with the Editor of Nature; or at any rate to suppose that there can be no productions of the former which 


\section{Editorial}

would not be accepted for publication by the latter. And I see no rẹason to believe this.

And then there is Broad's judgment on Spiritualism, in the text of the same work:

To sum up, from a fairly extensive reading of spiritualistic literature, and from a certain amount of personal experience of séances, I should say that the average 'spirit' is morally no worse than the average Fellow of Trinity, though there is a very marked difference in the intelligence of the two.

No smile broke the Vice-Provost's severity, but his words became milder: 'In view of what you say, I suppose he must have a sense of humour, but I thought he had none. When he was over here some years ago to give the Donnellan Lectures I took him for a walk along the banks of the Liffey, and as we walked I said to him, "Broad," I said, "the two most valuable things in life are philosophy and fish, trout and truth". And he didn't laugh at all, or even smile. He just looked at me rather strangely'.

Some readers may look at us rather strangely if we add another small Irish item from the stockpot where we fish for truth and other things in the days before each quarterly deadline. Many British and Irish television viewers will know the name and face of Miss Olivia O'Leary, once a presenter on the BBC's Newsnight series. Miss O'Leary pronounces her Christian name with an apostrophic pause between the ' $O$ ' and the 'livia', as if her full name were spelt 'O'Livia O'Leary'. Not long after first noticing this mannerism we saw on the programme of a one day conference in Cambridge the announcement of a paper to be given by Professor Onora O'Neill of the University of Essex. It was pleasing to see that the programme disguised Professor O'Neill as 'Professor O'Nora O'Neill'. Soon afterwards we noticed when listening to one of the BBC's Irish News commentators that such-and-such a view of certain events that had taken place in the Dail had now been confirmed by what he called 'O'Fficial O'Pinion'. 